\title{
Design and modeling of an advanced marine machinery system including waste heat recovery and removal of sulphur oxides
}

\author{
Frimann Nielsen, Rasmus; Haglind, Fredrik; Larsen, Ulrik
}

\section{Published in:}

Proceedings of ECOS 2013 - The 26th International Conference on Efficiency, Cost, Optimization, Simulation and Environmental Impact of Energy Systems

Publication date:

2013

Link back to DTU Orbit

Citation (APA):

Frimann Nielsen, R., Haglind, F., \& Larsen, U. (2013). Design and modeling of an advanced marine machinery system including waste heat recovery and removal of sulphur oxides. In Proceedings of ECOS 2013 - The 26th International Conference on Efficiency, Cost, Optimization, Simulation and Environmental Impact of Energy Systems Chinese Society of Engineering Thermophysics.

\section{General rights}

Copyright and moral rights for the publications made accessible in the public portal are retained by the authors and/or other copyright owners and it is a condition of accessing publications that users recognise and abide by the legal requirements associated with these rights.

- Users may download and print one copy of any publication from the public portal for the purpose of private study or research.

- You may not further distribute the material or use it for any profit-making activity or commercial gain

- You may freely distribute the URL identifying the publication in the public portal 


\title{
Design and modeling of an advanced marine machinery system including waste heat recovery and removal of sulphur oxides
}

\author{
Rasmus Frimann Nielsen $^{a, b}$, Fredrik Haglind $^{a, c}$ and Ulrik Larsen $^{a, d}$ \\ ${ }^{a}$ Department of Mechanical Engineering, Technical University of Denmark \\ Building 403, Nils Koppels Allé, DK-2800 Kgs. Lyngby, Denmark \\ b rasmus@frimann.org, ${ }^{\mathrm{C}}$ frh@mek.dtu.dk, ${ }^{d}$ ular@mek.dtu.dk
}

\begin{abstract}
:
In order to reduce the formation of acid rain and its harmful effects, stricter legislations on emissions of sulphur oxides from ships applies as of 2015 in emission control areas and globally in 2020 by the international maritime organization (IMO). Consequently, prices on low sulphur fuels are expected to increase drastically compared to those of heavy fuel oil, giving ship owners a strong incentive to find alternative ways of complying with the legislations. In addition, IMO regulations on carbon dioxide emissions and high fuel prices provide incentives for improving the efficiency of the machinery system. The wet sulphuric acid process has shown to be an effective way of removing sulphur oxides from flue gas of landbased coal fired power plants. Moreover, organic Rankine cycles are suitable for heat to power conversion for low temperature heat sources. This paper is aimed at designing and modelling a highly efficient machinery system which includes the removal of exhaust gas sulphur oxides. Numerical simulations are carried out using an open source software developed at Technical University of Denmark called Dynamic Network Analysis (DNA). The machinery system suggested in this paper consists of a two-stroke diesel engine, the wet sulphuric process for sulphur removal and an advanced waste heat recovery system including a conventional steam Rankine cycle and an organic Rankine cycle. The results are compared with those of a state-of-the-art machinery system featuring a two-stroke diesel engine and a conventional waste heat recovery system. The results suggest that an organic Rankine cycle placed after the conventional waste heat recovery system is able to extract the sulphuric acid from the exhaust gas, while at the same time increase power generation from waste heat by $32.9 \%$ and the combined cycle thermal efficiency by $2.6 \%$. The findings indicates that the technology has an energetic and environmental potential in marine applications, while still further research and development need to be done before it can be put into operation on ships.
\end{abstract}

\section{Keywords:}

Sulphur Oxides (SOx), Organic Rankine Cycle, Exhaust gas cleaning, Marine Diesel Engine, Combined cycle 


\section{Introduction}

More than $90 \%$ of all global trade is transported by sea summing up to 8.7 billion of loaded tons cargo by 2012 [101]. A great majority of the prime movers for ocean going ships are diesel engines and for large ships almost all are 2-stroke low speed diesel engines. This type of engine has become dominant because of its high efficiency and ability to use cheap heavy fuel oil (HFO). Reduction of the environmental impact and fuel consumption from this type of system is thus an important area, for which to reduce the impact on environment and consumption of resources on a global scale.

Heavy fuel oil is produced at the "bottom-end" of the oil refining process and consists of significant amounts of sulphur, with the world average sulphur content being $2.7 \%$ [104]. The exhaust emission of sulphur oxides $\left(\mathrm{SO}_{\mathrm{x}}\right)$ formed by combustion of fuels containing sulphur is regulated by the international maritime organization (IMO) through the marine air pollution regulations (MARPOL, Annex VI). Globally the sulphur content in marine fuels was reduced to maximum 3.5\% in 2012 and it is being drastically reduced to $0.5 \%$ from 2020 . This however is depending on the outcome of a review to be concluded by 2018, where it can be postponed to 2025 . Furthermore, the IMO have established emission control areas (ECA) for $\mathrm{SO}_{\mathrm{x}}$, sometimes also referred to as SECA, where stricter legislations apply. SECA includes the North Sea, the Baltic Sea and all sea in a distance of 200 nautical miles from the North American cost line including all coast areas of the United States of America, parts of Canada and the Hawaiian islands. By $1^{\text {st }}$ of January 2014 the United States Caribbean Sea area is expected to enter into effect. For SECA the limits on $\mathrm{SO}_{\mathrm{x}}$ are reduced stepwise from the current sulphur content of $1 \%$ to $0.1 \%$ in 2015 [103]. A graphical overview of the development in legislations on the sulphur content of marine fuels is given in Fig. 1.

If ship owners do not choose to switch between different fuels while entering SECA areas, IMO allows for other ways to comply with the sulphur limits. This is divided into primary, in which the formation of $\mathrm{SO}_{\mathrm{x}}$ is avoided, and secondary, in which $\mathrm{SO}_{\mathrm{x}}$ is formed but subsequently removed prior to discharge of the exhaust gas. [103].

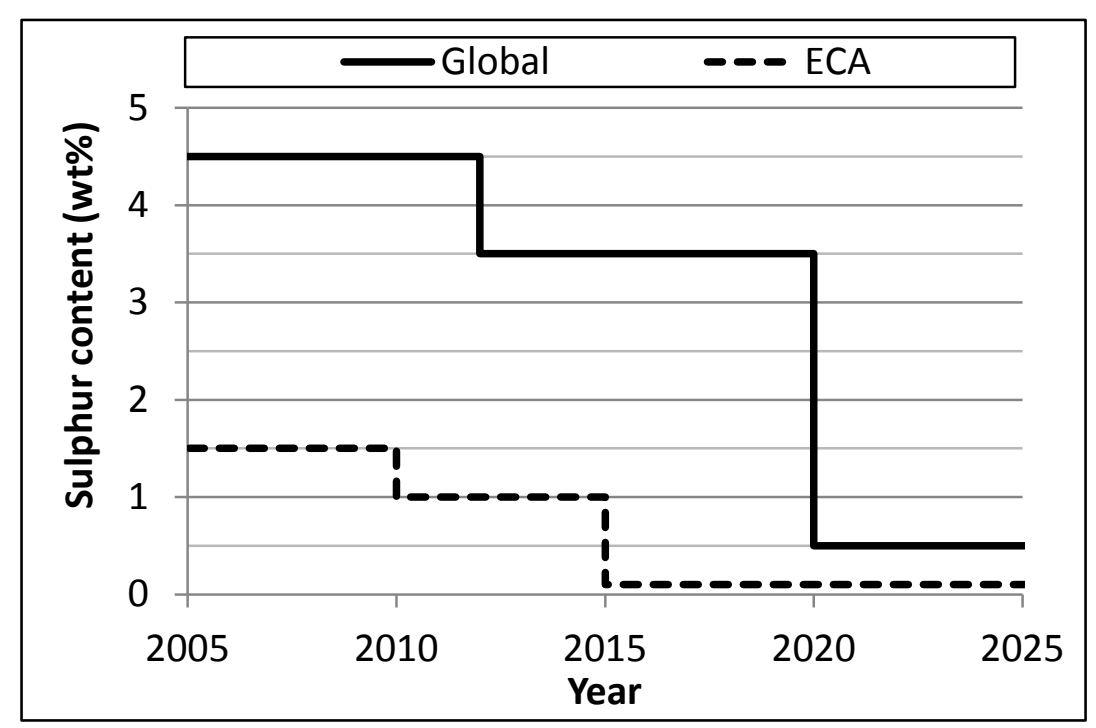

Fig. 1. $\mathrm{SO}_{x}$ limits of fuels for marine transportation globally and in emission control areas (ECA)

In marine transportation the fuel cost is estimated to make up two third of the total freight cost, explaining why fuel efficiency is receiving significant attention within the industry. The current price of distillate fuels is approximately 50\% higher than that of HFO [101] and the price difference is expected to increase further as the demand for distillate fuels will increase with legislations on $\mathrm{SO}_{\mathrm{x}}$ entering into effect. This trend gives ship owners incentives to find ways of using the cheaper HFO while still complying with legislations on emissions, thus implementing cost-effective exhaust gas after treatment systems is attractive. 
Land based power production have for a long time faced legislations on emissions of $\mathrm{SO}_{\mathrm{x}}$, and can be used to find inspiration in the search for effective exhaust gas after treatment systems. Coal fired power plants, which also contains significant amounts of sulphur, have employed Flue Gas Desulphurization (FGD), where an alkaline absorbent, typically limestone, is used to absorb $\mathrm{SO}_{2}$ under production of gypsum. Salty sea water is considered to be used as absorbent for marine application, commonly referred to as wet scrubbers. A well to wake study by Ma et al. [117] compares green house gas emissions and total energy consumption of different scrubber options as an alternative to switching to low sulphur distillate fuel. The study indicates that it is more attractive to install after treatment systems in form of sea water scrubbers compared to a switch to low sulphur fuels. However, a drawback of the wet scrubbers is that the heat contained in the exhaust gas is wasted and at the same time they use significant amounts of power to pump sea water to the wet scrubber [123].

A method not included in the study by Ma et al. [117] is the wet sulphuric acid (WSA) process, which was introduced and patented by Haldor Topsoe A/S in the late 1980s [110]. The WSA process is a process where a $\mathrm{SO}_{\mathrm{x}}$ and water vapor reacts and forms liquid sulphuric acid $\left(\mathrm{H}_{2} \mathrm{SO}_{4}\right)$ in high concentrations. The process requires that the exhaust gas is cooled down to a temperature below the dew point of sulphuric acid, while the heat from the process can be used for any suitable purpose.

Over the recent years power production from low temperature heat sources in general has received increasing attention. The organic Rankine cyle (ORC) is considered a promising candidate for this purpose, because the working fluid can be selected to suit relatively low temperature levels [107, 127, 128]. In a review of low grade heat conversion using ORC given by Vélez et al. [107], it is reported that commercial available ORCs exists in the range of 0.2 to 2 MWe. To the knowledge of the authors the first ORC onboard a ship is currently being tested on the new build MV Figaro providing a maximum output power of 0.5 MWe [108].

General studies of ORCs in combination with internal combustion engines $[125,126]$ exists, whereas a more limited number specifically with marine application exists. A review of waste heat recovery systems on two-stroke internal combustion engines aboard ships is given by Shu et al. [105] and a study by Larsen et al. compares the steam cycle, Kalina cycle and organic Rankine cycle for marine application [124]. The most conventional waste heat recovery system (WHRS) employed today consists of a power turbine expanding part of the exhaust gas to ambient pressure and a steam boiler, which is used in a Rankine cycle for electricity production. Either of the two can be employed alone or in a combination [106]. Common for all WHRS is that the exhaust gas temperature at the outlet of the boiler is kept above $160{ }^{\circ} \mathrm{C}$ to prevent sulphuric acid corrosion on boiler and piping. This restricts the power production from the WHRS, because more energy could be extracted by further lowering the exhaust gas temperature.

In this paper an exhaust gas after treatment system that integrates the WSA process in to the conventional WHRS is proposed. This is a methodology not found in the present literature. To further increase the energy efficiency of the propulsion system, the heat from the WSA process will be utilized in an organic Rankine cycle, where the extensive work found in literature [125, 126, 124, $107,127,128]$ can be drawn upon. The proposed system will enable ship owners and operators to continue to use the cheaper HFO, while still complying with future legislations on $\mathrm{SO}_{\mathrm{x}}$. The study is performed as case study where a reference plant, case 1, consisting of a 2-stroke marine diesel engine and a state-of-the-art WRHS is compared by means of numerical simulations against the proposed design, case 2 .

In the next section the reference plant, case 1 , and the proposed plant, case 2 , are presented together with the modeling methodology used. The main results are presented in section 3 , and the performance of case 1 and 2 are compared. Section 4 contains a discussion of the significance of the results and areas needing further research and development are discussed. Finally section 5 contains the conclusion of the present work. 


\section{Method}

\subsection{Case 1 - Reference plant}

The propulsion system of the container vessel Alexander Maersk was chosen for the concept study. Alexander Maersk has a container capacity of 1068 twenty-foot equivalent unit (TEU), which makes it a feeder class vessel [122]. Its prime mover is a MAN 7S50MC 2-stroke diesel engine, which has a maximum continuous rating (MCR) of 10,126 kW. The vessel is selected because it is mostly operated in coast-near areas, which makes it more vulnerable to legislations on $\mathrm{SO}_{\mathrm{x}}$. A main engine load of 75\% MCR was used with the ambient condition based on the ISO 3046-1:2002(E) and ISO 15550:2002(E) standard and fuel composition as given in Table 1.

Table 1. Ambient conditions and fuel composition

ISO ambient conditions

\begin{tabular}{ll}
\hline Barometric pressure & 1000 mbar \\
Turbocharger air intake temperature & $25{ }^{\circ} \mathrm{C}$ \\
Charge air coolant temperature & $25{ }^{\circ} \mathrm{C}$
\end{tabular}

\begin{tabular}{lc}
\hline $\mathrm{C}$ & $84.47 \% \mathrm{wt}$ \\
$\mathrm{H} 2$ & $11.43 \% \mathrm{wt}$ \\
$\mathrm{O} 2$ & $1.07 \% \mathrm{wt}$ \\
$\mathrm{N} 2$ & $0.30 \% \mathrm{wt}$ \\
$\mathrm{S}$ & $3.00 \% \mathrm{wt}$ \\
Lower heating value & $42700 \mathrm{~kJ} / \mathrm{kg}$ \\
Specific heat capacity & $2.1 \mathrm{~kJ} / \mathrm{kg}-\mathrm{K}$ \\
\hline
\end{tabular}

Fig. 2a shows a component diagram of the reference plant, which consist of a main engine, turbocharger, exhaust gas turbine, steam boiler with associated steam turbine, condenser and pump, and a generator. Following is a description of the reference plant.

Air is taken into the compressor part of the turbocharger (TCC) and feed to the cylinders of the main engine through a scavenge air receiver. After combustion the exhaust gas goes out to the exhaust gas receiver, from where the exhaust gas flow is split between the turbine part of the turbocharger (TCT) and an exhaust gas turbine, also called power turbine (PT). After the exhaust gas has passed the TCT and the PT the two flows are brought together again and are taken through a series of heat exchangers producing steam for a steam turbine. The steam turbine is connected to the same generator as the power turbine through a reduction gear. Part of the steam produced in the boiler is used for steaming services (SS). Steaming services is among others used to preheat the $\mathrm{HFO}$ to a temperature of $120^{\circ} \mathrm{C}$, because of its high viscosity, as well as other heating purposes. The feedwater to the steam cycle is preheated by the jacket water from the main engine in the jacket water preheater (JWP) to a temperature of $85^{\circ} \mathrm{C}$. The compressed intake air is taken trough two air coolers AC1 and AC2. AC1 is used to preheat the feed water for the steam cycle, while AC2 uses seawater to further cool down the intake air before it enters the scavenge air receiver.

The WHRS is of the configuration proposed by Man Diesel \& Turbo with a two-pressure level steam cycle, low pressure being 4.275 bar and the high pressure being 10 bar, while condenser pressure was set to 0.07 bar [106]. Parameters for simulating the main engine is obtained from a computer simulation program, CEAS, provided by manufacturer [120] and a summary of all parameters used to simulate the reference plant is given in Table 2. The combustion in the main engine had an excess air coefficient of 3.08 and the composition of the exhaust gas is as given in Table 3. For the exhaust gas ideal gas properties were assumed. 
Table 2. Parameters used to model case 1 - reference plant.

\begin{tabular}{ll}
\hline Main Engine and Turbocharger & \\
\hline Brake Power & $7678 \mathrm{~kW}$ \\
Temperature after air cooler & $31.4{ }^{\circ} \mathrm{C}$ \\
Scavenge air pressure & $3.098 \mathrm{bar}$ \\
Specific fuel oil consumption (SFOC) & $176.68 \mathrm{~g} / \mathrm{kWh}$ \\
Exhaust gas temperature (before TCT) & $420{ }^{\circ} \mathrm{C}$ \\
Exhaust gas pressure (before TCT) & $2.906 \mathrm{bar}$ \\
Main engine - Jacket water cooling & $1074 \mathrm{~kW}$ \\
Main engine - Other heat losses & $651 \mathrm{~kW}$ \\
Turbocharger compressor - isentropic efficiency & $82.5 \%$ \\
Turbocharger turbine (incl. Mechanical losses) - isentropic efficiency & $82.5 \%$ \\
Air intake - pressure loss & $90 \mathrm{mmWC}$ \\
Scavenge air coolers - pressure loss & $150 \mathrm{mmWC}$ \\
\hline Waste heat recovery system & $82.5 \%$ \\
\hline Power turbine - isentropic efficiency & $78.0 \%$ \\
Steam turbine (low pressure part) - isentropic efficiency & $78.0 \%$ \\
Steam turbine (high pressure part) - isentropic efficiency & $98.0 \%$ \\
Gear (power turbine to steam turbine) - mechanical efficiency & $98.0 \%$ \\
Gear (steam turbine to generator) - mechanical efficiency & $98.0 \%$ \\
Generator - Electrical efficiency & $12 \mathrm{mbar}$ \\
Heat exchangers gas side (all) - pressure drop & $0 \mathrm{mbar}$ \\
Heat exchangers steam side (all) - pressure drop & $85.0 \%$ \\
Feed Water pump - isentropic efficiency & $175 \mathrm{~kW}$ \\
Steaming service - Heat load & $15{ }^{\circ} \mathrm{C}$ \\
Heat exchangers - Minimum pinch point temperature difference &
\end{tabular}

Table 3. Composition of exhaust gas (\%mol).

\begin{tabular}{ll}
\hline $\mathrm{O}_{2}$ & 13.750 \\
$\mathrm{~N}_{2}$ & 75.812 \\
$\mathrm{CO}_{2}$ & 4.703 \\
$\mathrm{H}_{2} \mathrm{O}$ & 4.771 \\
$\mathrm{Ar}$ & 0.902 \\
$\mathrm{SO}_{2}$ & 0.062 \\
\hline
\end{tabular}

\subsection{Simulation software DNA}

The main engine and WHRS is modeled in steady state in the numerical simulation software called Dynamic Network Analysis (DNA). DNA is a simulation tool used for energy systems analyses $[112,113]$. It is the present result of an ongoing development at the Department of Mechanical Engineering, Technical University of Denmark. In DNA the physical model is formulated by connecting the relevant component models through nodes and by including operating conditions for the complete system. The physical model is converted into a set of mathematical equations to be solved numerically. The mathematical equations include mass and energy conservation for all components and nodes, as well as relations for thermodynamic properties of the fluids involved. In addition, the components include a number of constitutive equations representing their physical properties, e.g. heat transfer coefficients for heat exchangers and isentropic efficiencies for compressors and turbines. The program includes a component library with models for a large number of different components existing within energy systems. 


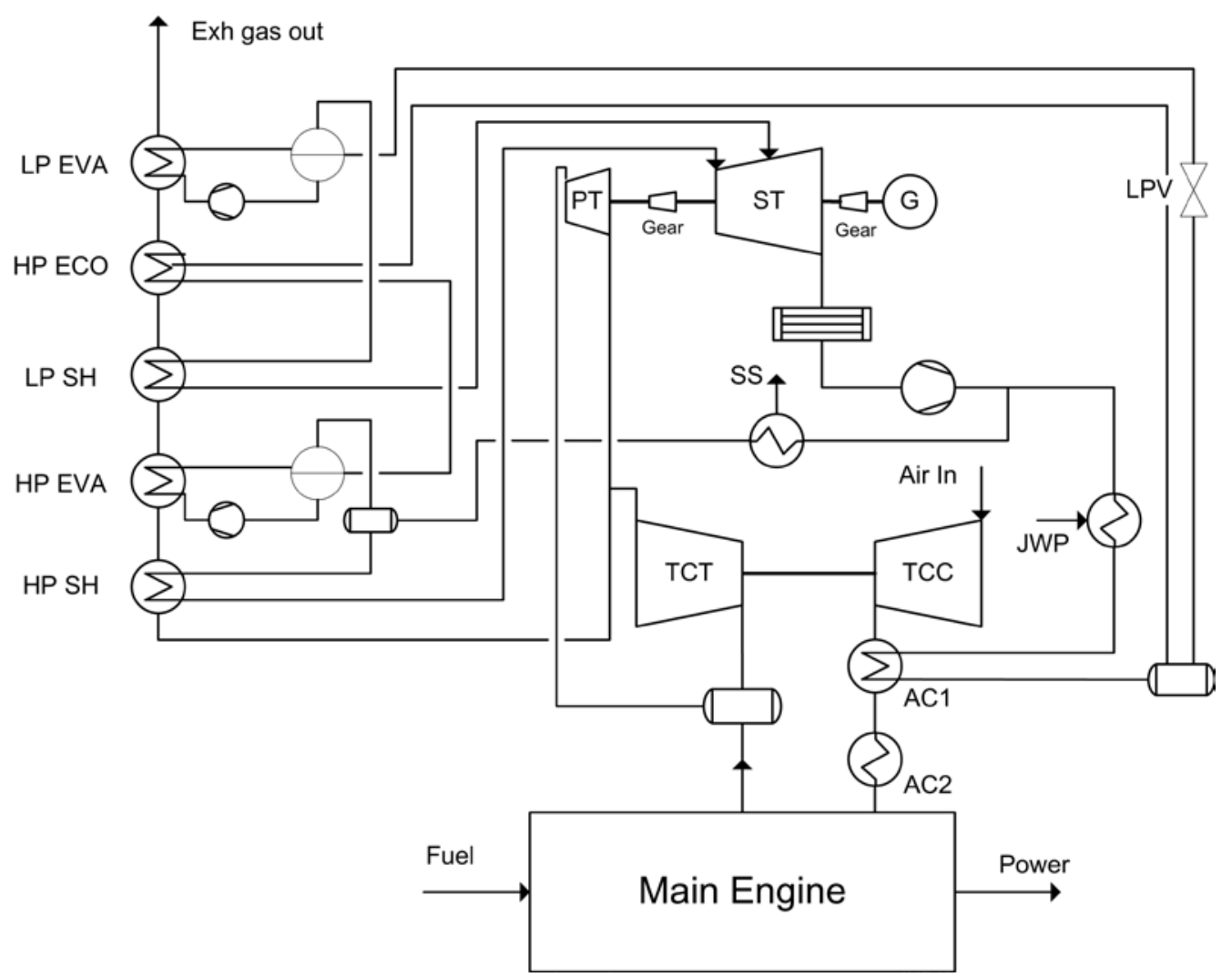

(a)

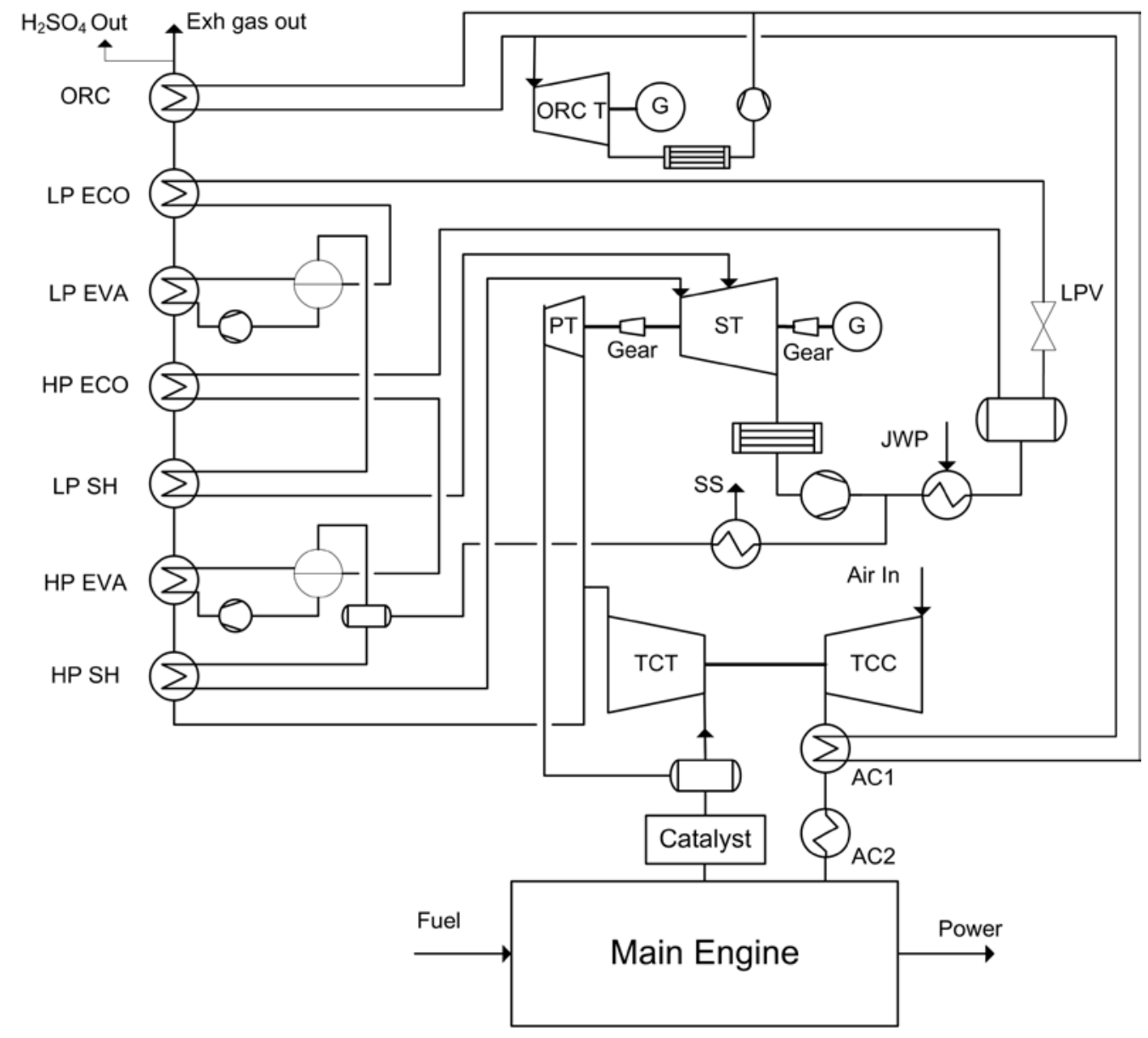

(b)

Fig. 2. Component diagram of: a) case 1 - reference plan, b) case 2 - proposed design. 


\subsection{Formation of sulphuric acid.}

The wet sulphuric acid process produces sulphuric acid in high concentrations by cooling down exhaust gas containing water vapor below the dew point of sulphuric acid. The chemical process in the formation of sulphuric acid is here described in order to understand how it can be implemented in to the conventional WHRS of a ship.

The amount of $\mathrm{SO}_{\mathrm{x}}$ in the exhaust gas is a simple function of the amount of sulphur in the fuel and cannot be controlled by the combustion process [109]. Most of the $\mathrm{SO}_{\mathrm{x}}$ in the exhaust gas is $\mathrm{SO}_{2}$ and only a small amount is $\mathrm{SO}_{3}$. However $\mathrm{SO}_{2}$ will react with oxygen to form $\mathrm{SO}_{3}$ in the oxidation process (R1). When sulphur-trioxid is formed it will react with the water vapour in the exhaust gas forming sulphuric acid in a gaseous state (R2) and by further cooling down the exhaust gas sulphuric acid will condense (R3) [114].

$$
\begin{aligned}
& \mathrm{SO}_{2}+1 / 2 \mathrm{O}_{2} \rightarrow \mathrm{SO}_{3}+99 \mathrm{~kJ} / \mathrm{mole} \\
& \mathrm{SO}_{3}+\mathrm{H}_{2} \mathrm{O} \rightarrow \mathrm{H}_{2} \mathrm{SO}_{4} \text { (gas) }+100 \mathrm{~kJ} / \text { mole } \\
& \mathrm{H}_{2} \mathrm{SO}_{4} \text { (gas) }+0.28 \mathrm{H}_{2} \mathrm{O} \rightarrow \mathrm{H}_{2} \mathrm{SO}_{4}(95 \% \text { conc. })+80 \mathrm{~kJ} / \mathrm{mole}
\end{aligned}
$$

The oxidation process (R1) is the rate dependent process, and a catalyst is needed in order for the process to happen within the exhaust gas system [109]. A catalyst for this purpose can be based on vanadium pentoxide $\left(\mathrm{V}_{2} \mathrm{O}_{5}\right)$, which operates efficiently down to temperatures of $370{ }^{\circ} \mathrm{C}$ [118]. The catalyst therefore has to be placed before the turbine part of the turbocharger.

The exhaust gas needs to be taken significantly below the dew point temperature to ensure condensation of sulphuric acid (R3). The condensation temperature depends on the partial pressure of $\mathrm{SO}_{3}$ and water vapor and can be estimated by the method given by Okkes [111]

$$
\mathrm{T}_{\mathrm{dew}}=203.25+27.6 \log \left(\mathrm{p}_{\mathrm{H} 2 \mathrm{O}}\right)+10.83 \log \left(\mathrm{p}_{\mathrm{sO}}\right)+1.06\left(\log \left(\mathrm{p}_{\mathrm{sO} 3}\right)+8\right)^{2.19}
$$

where $\mathrm{p}_{\mathrm{H} 2 \mathrm{O}}$ and $\mathrm{p}_{\mathrm{sO}}$ are the partial pressures of $\mathrm{H}_{2} \mathrm{O}$ and $\mathrm{SO}_{3}$ in atmosphere respectively. With the exhaust gas composition given in Table 3 and assuming that all $\mathrm{SO}_{2}$ is converted to $\mathrm{SO}_{3}$ is the dew point temperature found to be $164.8^{\circ} \mathrm{C}$.

\subsection{Case 2 - Proposed design}

The proposed design, which can be seen in Fig. 2b, is similar to the reference plant, but a catalyst is placed between the main engine and turbocharger turbine and a heat exchanger is placed at the outlet of the steam boiler. The extra heat exchanger in the exhaust gas flow termed ORC in Fig. $2 b$ serves the purpose of extracting the sulphuric acid from the exhaust gas and providing heat to an organic Rankine cycle.

The temperature of intake air out of the compressor (TCC) is approx $164{ }^{\circ} \mathrm{C}$, why this was chosen to be used as a heat reservoir for the ORC as well. In the reference plant the air cooler (AC1) was used to preheat the steam and thus no LP economiser was needed. This is however needed in the proposed design as the feed water is only preheated to $85{ }^{\circ} \mathrm{C}$ in the jacket water preheater (JWP). Consequently the LP level of the steam boiler was raised from 4.25 to 4.75 bar.

Selection of working fluid for the ORC is a non-trivial task. Apart from matching the thermodynamic properties of the fluid there are concerns about the fluid hazard levels with regards to flammability, toxicity and environmental concerns, mainly global warming potential and ozone depletion potential. Special concerns about hazard levels needs to be taken for marine applications and the IMO SOLAS regulations state that the flash point of a fluid in a machinery space may not be lower than $60{ }^{\circ} \mathrm{C}$, thus all hydrocarbons are excluded. Quoilin and Lemort [115] suggests R123 and R245fa as working fluids for the temperature ranges considered in this study and a more recent 
study by Larsen et al. of working fluids for marine applications suggest R245fa and R236ea as suitable for marine applications. R123 is to be faced out in the recent future and thus it was chosen to use R245fa as working fluid for this study.

All parameters used to model main engine and conventional WHRS is kept the same as in the reference plant. The pump and turbine of the ORC were both given isentropic efficiencies of $80 \%$ and no pressure loss were accounted in the heat exchangers on either side. A mechanical efficiency of $98 \%$ was introduced between ORC turbine and generator and an electrical efficiency of $98 \%$ was assumed for the ORC generator. Pressure drop is not accounted in the catalyst, nor is the heat increase from the chemical reaction (R1) as this is expected to be weighted out with the heat loss from the catalyst (see section 3).

The performance of the ORC was modelled using Engineering Equation Solver (C) [129] and added to the results of the simulation done in DNA. The ORC performance was validated by comparison to similar studies $[126,127,128]$. A heat temperature diagram of the steam boiler and organic Rankine cycle from case 2 is given in Fig. 3.

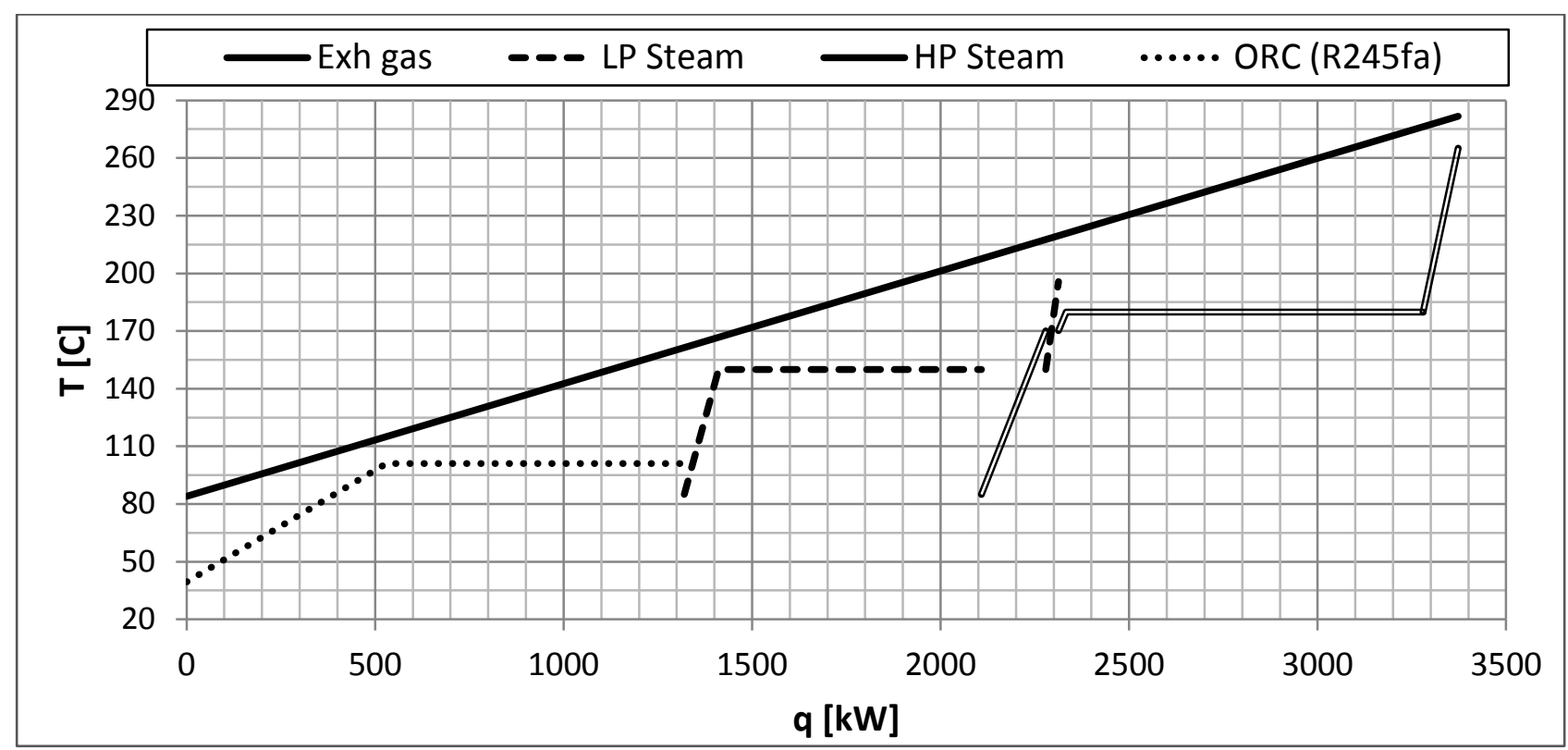

Fig. 3. Heat-temperature diagram of steam boiler and organic Rankine cycle

\section{Results}

The performance data of the reference plant and the proposed plant is summarised in Table 4. The main engine and turbocharger performance is indifferent in the two cases. The power production from the conventional part of the waste heat recovery system (power turbine and steam turbine) is $7.2 \%$ lower in case 2 compared to the reference plant. This is because the power production from the steam turbine is lowered by $48 \mathrm{~kW}$ from 466 to $418 \mathrm{~kW}$. In case 2 the electric power production from the ORC is found to be $270.1 \mathrm{~kW}$, which imposes an increase in total waste heat recovery power production of $32.9 \%$. A comparison of the overall thermal efficiency for case 1 and 2 and the total power production from waste heat recovery is given in Fig. 4.

The operation pressure of the organic Rankine cycle was optimised with respect to maximum power output. The pressure was found to be 13 bar, which resulted in the exhaust gas temperature being lowered from 161.7 to $84.0{ }^{\circ} \mathrm{C}$ under the constraint of a minimum temperature difference of $15^{\circ} \mathrm{C}$. This is considered sufficiently low for the sulphuric acid to be condensed. 
Table 4. Simulation results.

\begin{tabular}{lccc}
\hline Main Engine and Turbocharger & Case 1 & Case 2 & \\
\hline Main engine - brake thermal efficiency & 47.72 & 47.72 & $\%$ \\
Main engine - mass flow of air in & 15.99 & 15.99 & $\mathrm{~kg} / \mathrm{s}$ \\
Main engine - mass flow of exhaust gas & 16.37 & 16.37 & $\mathrm{~kg} / \mathrm{s}$ \\
Main engine - excess air coefficient of combustion & 3.082 & 3.082 & - \\
Waste heat recovery system & & & \\
\hline Thermal efficiency of combined cycle & 51.92 & 53.29 & $\%$ \\
Net power production by WHRS & 675 & 626.7 & $\mathrm{~kW}$ \\
Net power production by ORC & - & 270.1 & $\mathrm{~kW}$ \\
Exhaust gas outlet temperature & 161 & 84.0 & ${ }^{\circ} \mathrm{C}$ \\
\hline
\end{tabular}

It can be shown that when assuming that all sulphur in the fuel is converted into sulphuric acid the production of sulphuric acid will be given by

$$
\dot{m}_{H 2 S O 4}=\frac{\dot{m}_{f u e l} x_{S}}{M W_{S}} M W_{H 2 S O 4}
$$

The fuel consumption is found to be $1337.4 \mathrm{~kg} / \mathrm{h}$ and thus the production of sulphuric acid is estimated to be $122.7 \mathrm{~kg} / \mathrm{h}$, which is roughly $10 \%$ of the fuel consumption.

The heat produced by the chemical reactions from the oxidation of $\mathrm{SO}_{2}$ (R1) as well as formation (R2) and condensation (R3) of sulphuric acid will be $34.4 \mathrm{~kW}, 34.8 \mathrm{~kW}$ and $27.8 \mathrm{~kW}$ respectively. With a heat capacity of the exhaust gas of $1.08 \mathrm{~kJ} / \mathrm{kg}-\mathrm{K}$ this will correspond to a temperature rise of the exhaust gas between 1.57 and $1.97{ }^{\circ} \mathrm{C}$. These relatively small temperature increases due to the chemical reactions was neglected in the calculations of case 2 as also heat losses were neglected.

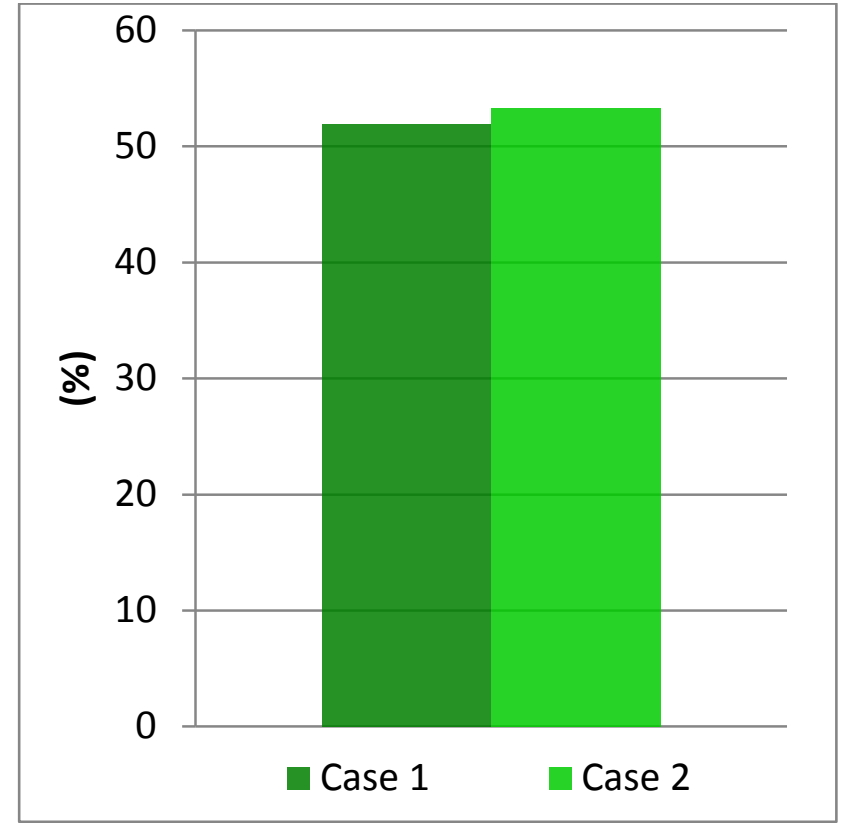

(a)

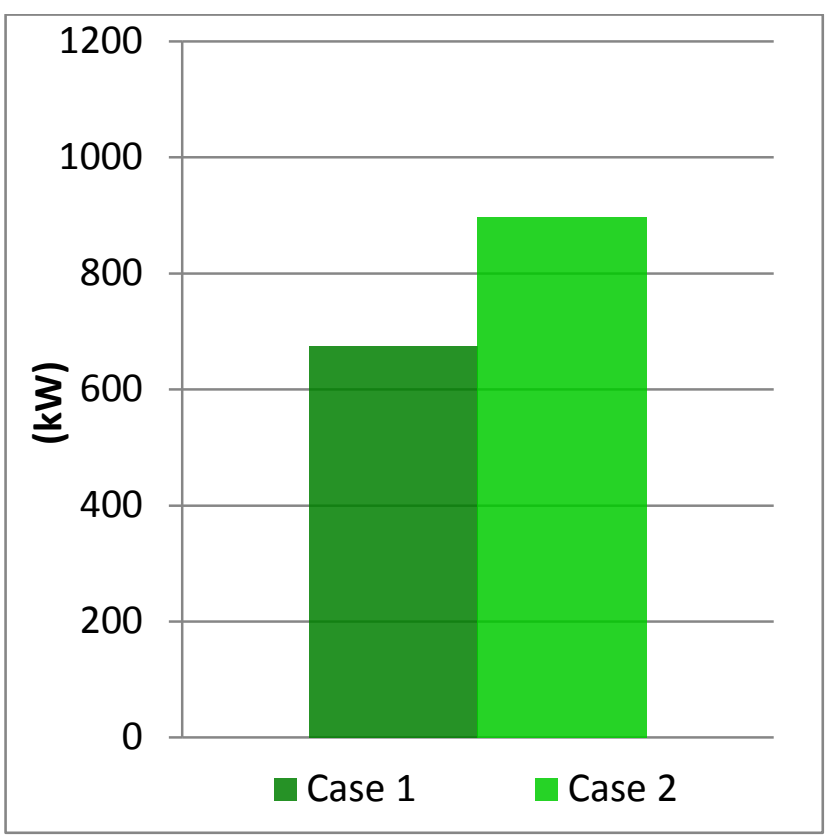

(b)

Fig. 4. Comparison between reference and proposed plant: a) thermal efficiency of combined cycle, b) power production by waste heat recovery.

\section{Discussion}

Considering the 1.37 points increase of the combined cycle system thermal efficiency, it is concluded that the implementation of the wet sulphuric acid process is feasible from an energetic perspective. Furthermore, the implementation enables the ship owner or operator to use the much 
cheaper HFO, while still complying with the legislations on $\mathrm{SO}_{\mathrm{x}}$. The results regarding the ORC is very much conceptual and further studies are needed in order to identify the following: 1) the size and practical placement of a catalyst placed before the turbocharger turbine and how effective the conversion of $\mathrm{SO}_{2}$ to $\mathrm{SO}_{3}$ may be, 2) will sufficient quantities of sulphuric acid be condensed in the heat exchanger of the ORC and not in other places and 3) how can a system collecting and handling the sulphuric acid be implemented in the ship design.

Regarding point 2) above here, the WSA process is claimed to remove up to $98 \%$ of $\mathrm{SO}_{\mathrm{x}}$ and the process is operating on land based power plants [114]. Furthermore, a design suitable for marine applications needs to be found. Glass or ceramic materials may be used due to the corrosiveness of the sulphuric acid, but metallic heat exchangers with special coatings could also be an option, as these will have better heat transfer properties and thus smaller dimensions.

Polytetrafluoroethylene (PTFE), commonly known as Teflon ${ }^{\circledR}$, is suggested as well as Tantalum coated heat exchangers might be an option.

Other possible of designs of the WHRS could also be studied, e.g. a system consisting solely of one or more ORC cycles, possibly employing different working fluids or to use dual-pressure ORC. Also there is room for further improvements by reducing the exhaust gas outlet temperature further.

Furthermore part load operation of the system needs to be considered ensuring that the sulphuric acid is condensed and collected under all conditions.

\section{Conclusion}

The restriction on sulphur content in fuel for ships will be increased drastically in 2015 for operation in special emission control areas, and globally in 2020. Shipowners must comply with these legislations, and therefore it is necessary to find an effective method of reducing emissions of sulphur from ships.

The wet sulphuric acid (WSA) process has shown to be an effective way of removing sulphur oxides from the flue gas of land-based power plants and thus the purpose of this paper has been to show the potential of implementing such technology in ships.

A concept study was carried out with a reference plant being a combined cycle made up of a 2-stroke low speed marine diesel engine and a waste heat recovery system of the configuration proposed by MAN Diesel \& Turbo with a dual-pressure steam cycle. A new waste heat recovery systems was proposed, modelled and evaluated against the reference plant at a main engine load of $75 \%$ MCR. The proposed systems has the purpose of extracting the sulphuric acid from the exhaust gas before it is sent to the ambient, while at the same utilize the heat from the exhaust gas in an organic Rankine cycle. It was found that it requires a catalyst as well as a component that takes the temperature of the exhaust gas below the dew point of sulphuric acid, approximately $164{ }^{\circ} \mathrm{C}$, in order for the acid to condense and be extracted. The production of sulphuric acid from combustion of a $3 \%$ sulphur HFO was estimated to be $122.7 \mathrm{~kg} / \mathrm{h}$, which is equivalent to $9.2 \%$ of the fuel consumption.

The proposed plant, case 2, is built up as the reference plant, but with an organic Rankine cycle placed "on top" of the original waste heat recovery system. The heat exchangers of the organic Rankine cycle is placed after the steam boiler, and is the last component the exhaust gas passes through before it is sent to the ambient. The heat exchanger is also the component where the sulphuric acid is condensed and extracted. Furthermore a catalyst is placed before the turbocharger turbine to enhance the oxidation of $\mathrm{SO}_{2}$.

By using R245fa as working fluid and a maximum pressure of 13 bar for the ORC, the results suggest that an increase in power output of the WHR system by $32.9 \%$ would be obtainable. This corresponds to an increase of the combined cycle efficiency by $2.6 \%$.

These findings indicates that the proposed plant can provide energetic and environmental advantages in marine applications, but further research and development needs to be done before the concept can be applied onboard ships. 


\section{Acknowledgments}

The authors would like to express their gratitude to Thomas Eefsen, Peter Ring, Christian Løth, Jørn Kahle, Ole Graa Jacobsen and Per Hother Rasmussen from Maersk Maritime Technology for providing useful discussions and inspiration to the development of this work. Kurt Christensen from Haldor Topsoe A/S is also thanked for his guidance.

\section{Nomenclature}

$\begin{array}{ll}\text { AC1 } & \text { Air cooler } 1 \\ \text { AC2 } & \text { Air cooler } 2 \\ \text { DNA } & \text { Dynamic Network Analysis - computer simulation tool } \\ \text { ECA } & \text { Emission control area } \\ \text { ECO } & \text { Economiser } \\ \text { EES } & \text { Engineering Equation Solver } \text { C } \\ \text { EVA } & \text { Evaporator } \\ \text { HFO } & \text { Heavy fuel oil } \\ \text { HP } & \text { High pressure } \\ \text { IMO } & \text { International maritime organisation } \\ \text { JWP } & \text { Jacket water preheating } \\ \text { LP } & \text { Low pressure } \\ \text { LPV } & \text { Low pressure valve } \\ \text { MCR } & \text { Maximum continuous rating } \\ \text { NO } & \text { Nitrogen oxides } \\ \text { PT } & \text { Power turbine } \\ \text { SFOC } & \text { Specific fuel oil consumption } \\ \text { SH } & \text { Superheater } \\ \text { SO } & \text { Sulphur oxides } \\ \text { SS } & \text { Steaming services } \\ \text { ST } & \text { Steam turbine } \\ \text { TC } & \text { Turbocharger } \\ \text { TCC } & \text { Turbocharger compressor } \\ \text { TCT } & \text { Turbocharger turbine } \\ \text { WHRS } & \text { Waste Heat Recovery System }\end{array}$

\section{References}

[101] United Nations Publication, Review of Maritime Transport 201. Available at $<\underline{\text { http:// - }}$ unctad.org /en/PublicationsLibrary/rmt2012_en.pdf > [accessed 21.02.2013].

[102] Eyringer V, Köhler HW, Lauer A, Lemper B. Emissions from international shipping: 2. Impact of future technologies on scenarios until 2050. J Geophys Res 2005;110:D17306.

[103] International Maritime Organisation. Regulations. Available at <http://www.imo.org/OurWork/Environment/PollutionPrevention/AirPollution/Pages/Sulphur-oxides-(SOx)\%E2\%80\%93-Regulation-14.aspx > [accessed 21.02.2013].

[104] Endresen Ø, Sørgård E, Sundet JK, Dalsøren SB, Isaksen ISA, Berglen TF, et al. Emission from international sea transportation and environmental impact. J Geophys Res 2003;108:D17. 
[105] Shu, G. Et al., A review of waste heat recovery on two-stroke IC engine aboard ships. Renew Sust Energ Rev 2012;19:385-401.

[106] Man Diesel \& Turbo, Waste Heat Recovery System (WHRS). Available at $<$ http://www.mandieselturbo.com/files/news/filesof17740/5510-0136-00pp_low.pdf $>$ [accessed 21.02.2013].

[107] Vélez et al., A technical, economical and market review of organic Rankine cycles for the conversion of low-grade heat for power generation. Renew Sust Energ Rev 2012;16:41754189.

[108] Opcon Marine, Commissioning and testing of first reference installation of Opcon technology for ships. Available at $<\underline{\text { http://www.opcon.se/web/First_installation_1_1.aspx }>}$ [accessed 21.02.2013].

[109] Woodyard, D., Pounder's Marine Diesel Engine and Gas Turbines (9th Edition). Elsevier; 2009.

[110] Haldor Topsoe, Website on WSA process. Available at $<$ http://www.topsoe.com/business_areas/air_pollution_control/processes/wsa.aspx [accessed 21.02.2013].

[111] Okkes, A.G., Get acid dew point of flue gas. Hydrocarb Process 1987;66(7):53-56.

[112] Elmegaard B. Simulation of boiler dynamics - development, evaluation and application of general energy system simulation tool. Ph.D. thesis, Technical University of Denmark, Denmark; 1999.

[113] Elmegaard B, Houbak N. DNA - a general energy system simulation tool. Proceedings of SIMS 2005, Trondheim, Norway; 2005.

[114] Laursen, J. K., Halder Topsoe A/S, Denmark, Details advances in sulphur recovery by the WSA process. Hydrocarbon Engineering 2007;12(8):47-51.

[115] Quoilin, S., Lemort, V., Technological an economical survey of Oranic Rankine Cycle Systems, European conference on Economics and management of energy in industry, 2009 April; Vilamoura, Portugal.

[116] Haglind, F., A review on the use of gas and steam turbine combined cycles as prime movers for large ships. Part III: Fuels and emissions. Energ Convers Manage 2008;49:3476-3482.

[117] Ma, H., Steernberg, K., Riera-Palou, X., Tait, N, Well-to-wake energy and greenhouse gas analysis of SOX abatement options for the marine industry. Transport Res D-Tr E 2012;17(4):301-308.

[118] Haldor Topsoe A/S, VK-W series - Wet gas sulphuric acid catalysts. Available at $<$ http://www.topsoe.com/business_areas/air_pollution_control/processes/wsa.aspx $>$ [accessed 22.02.2013].

[119] Man Diesel \& Turbo, Soot deposit and fires in exhaust gas boilers. Available at $<$ http://www.mandieselturbo.com/files/news/filesof11026/5510-0065-01ppr_low.pdf> [accessed 22.02.2013].

[120] Man Diesel \& Turbo, CAES - Engine room dimensioning. Available at $<$ http://www.mandieselturbo.com/ceas/index.html > [accessed 22.02.2013].

[121] Larsen, U., Pierobona, L., Haglind, F., Gabrielii, C., Design and optimisation of organic Rankine cycles for waste heat recovery in marine applications using the principles of natural selection. Energy, submitted.

[122] Man Diesel \& Turbo, Propulsion trends in container vessels. Available at $<$ http://www.mandieselturbo.com/ceas/index.html > [accessed 24.02.2013] .

[123] Andreasen, A., Mayer S., Use of Seawater Scrubbing for SO2 Removal from Marine Engine Exhaust Gas. Energ Fuel 2007;21:3274-3279.

[124] Larsen, U., Haglind, F., Sigthorsson, O., A comparison of advanced heat recovery power cycles in a combined cycle for large ships In: ECOS 2013: Proceedings of the 26th 
International Conference on Efficiency, Cost, Optimization, Simulation, and Environmental Impact of Energy Systems; 2013 Jun 16-19; Guilin, China.

[125] Bombarda P, Invernizzi CM, Pietra C. Heat recovery from Diesel engines: A thermodynamic comparison between Kalina and ORC cycles. APPL THERM ENG 2010;30(2-3):212.

[126] Iacopo, V., Gambarotta, A., Internal combustion engine (ICE) bottoming with organic Rankine cycles (ORCs). Energy 2009;35:1084-1093.

[127] Schuster, A., Karellas, D., Aumann, R., Efficiency optimization potential in supercritical organic Rankine cycles. Energy 2010;35(2):1033-1039.

[128] Quoilin,S., Aumann, R., Grill, A., Schuster, A., Lemort, V., Spliethoff, H., Dynamic modeling and optimal control strategy of waste heat recovery Organic Rankine Cycles. Appl energy 2011;88(6):2183-2190.

[129] Engineering Equation Solver (C), Computer software. Available at $<$ www.fchart.com $>$. 